\title{
日本の文化財建造物における保存古材の取り扱いの変遷 \\ STUDY ON DEVELOPMENT OF JAPANESE HISTORY FOR PRESERVATION OF REMOVED PARTS FROM ARCHITECTURAL CULTURAL PROPERTIES
}

\author{
清 永 洋 平*1 \\ Yohei KIYONAGA
}

\begin{abstract}
The author wishes to explore the development of Japanese history for preservation of removed parts from architectural cultural properties while focusing on the selection criteria for its preservation. Initially by tracing the development of the selection criteria with the guidelines for the conservation projects. Secondly by making the list of removed parts designated as cultural properties, and analyzing it separated into 6 types. Thirdly by finding the first removed parts or the first report of ones for the conservation projects.
\end{abstract}

Keywords : architectural cultural properties, preservation for removed parts, selection criteria 文化財建造物,保存古材,選別の方針

\section{1. 緒言}

日本の文化財建造物の保存修理では、用いられてきた部材を最大 限に尊重している。部材に経年による劣化や腐朽及び破損があれば、 その箇所を繕い、強度が不足する場合には補強を施すなど、構造上 支障のない範囲で部材を再用している。

しかし、その対応が困難な場合や、過去の姿に復原する方針によ り、不再用となった場合、取り外された部材の中から一部を選んで、 建造物の小屋組内やその近辺に、古材として保管(以下、保存古材と 記す。）を図っている。

オリジナルの材質や当時の技法を内包する保存古材は、図面作製、 写真撮影及びそれらを纒めた修理工事報告書(以下、工事報告書と記 す。）と同様に、保存修理の内容を記録する有効な方法の一つとし て国内外に広く認識されている注 1)。また、近年では保存古材を用 いた科学的な調查研究も進展し、その重要性も高まりつつある注 2)。

しかし、これまでの保存修理史の既往研究では、保存古材に焦点 を当てた考察は見当たらず、保存古材の取り扱いの変遷については あまり注目されてこなかった注3)。また、各地で保管され、膨大な数 に上るとみられる保存古材に対して、個別分散的な調查はあるもの の、網羅的な把握はなく、その全体像も判然としていない注 4)。

そこで、本稿は、保存古材の取り扱いの変遷を、行政資料に現れ る文化財建造物の保存古材を選別する際の方針(以下、方針と記す。) に着目して明らかにした上で、網羅的に把握可能な国宝・重要文化 財建造物の附に指定された建築部材（以下、附指定古材と記す。）に 基づき、その実態を把握することを目的とする。

本稿の構成はまず、古社寺保存法(明治 30 年(1897) )、国宝保存 法(昭和 4 年(1929) ）、文化財保護法(昭和 25 年) ）の各時代におけ る行政資料の中から、方針の有無とその変遷を明らかにする。次に
附指定古材の類型化を通じてその時代的特徵を明らかにし、先に導 いた方針と諸類型を照合し、その実態を把握する。さらに行政資料 に方針がない時期の保存古材の取り扱いを、最初期の解体修理にお ける保存古材の実例や工事報告書を通じて検討する。以上をもとに、 文化財建造物における保存古材の取り扱いの変遷を明らかにする。

\section{2. 行政資料からみた保存古材の取り扱いの変遷}

\section{1 現在の保存古材の取り扱い}

最初に現在の保存古材の取り扱いを確認しておく。文化庁『国宝 重要文化財(建造物)保存修理事業実務の手引き』(平成 30 年(2018)6 月)に拠れば注 5)、文化財建造物の保存修理事業は、保存修理の経験 を有し、かつ文化庁が承認する主任技術者の設計監理のもと、破損 状況に応じて修理が進められている。

各々の修理の工程で、部材の性能を調査するが、劣化・腐朽・破 損した部材を取り替える場合、不再用材が発生寸る。また、大規模 修理では解体調査を踏まえ現状維持、復原、あるいは管理行為や活 用内容を含めた修理方針が決定される。その結果として意匠や構造 の復旧、管理、活用のため、やむを得ず不再用材が発生する。

不再用材はその中から「現状変更の資料としたもの及び将来重要 な参考資料となり得るもの」注 6)を保存古材として選別し、それら以 外は通常は廃棄される。全部材の所有権はその建造物の所有者にあ るが、不再用材の保存又は廃充の別の判断は主任技術者の調査、文 化庁等の行政の指導下、所有者の意向、事業規模、事業期間、保管 場所の規模等、総合的に検討されて、保存される部材の選択と管理 が決定されている。

保存古材のうち、建造物と一体となって価值を形成する建築部材 は、建造物本体の附として指定され、保護の措置が図られている注 7)。 


\section{2 方針を示す行政資料}

文化財建造物の保存修理における国の考え方を示寸行政資料のう ち、保存古材の選別の方針を示すものは、古社寺保存法時代にはな い。国宝保存法時代では、(1)文部省「国宝建造物維持修理要項」(昭 和 15 年 3 月 7 日文部次官決定) 注8)があり、文化財保護法時代には、 (2)文化財保護委員会「国宝及重要文化財建造物解体修理心得」(昭和 31 年 10 月) 注 9)、(3)文化庁文化財保護部建造物課『重要文化財建造 物保存修理技術者実務必携 1 (修理設計の心得と工事事務の心得)』 （昭和 49 年 8 月）、(4)文化庁文化財部建造物課『文化財建造物保存 修理補助事業実務の手引き』(平成 15 年 8 月初版、平成 30 年 6 月 最終改訂）の 3 つがあり、計 4 つの資料を見出せる。

\section{3 各資料における方針とその変遷}

(1)では、「維持修理二際シ使用不能トナリタル古材ニシテ學術上 又八由緒上保存スベキ價值アリト認メラルルモノ八適當ナル方法ニ 依リ之ヨ保存スルコト」とあるから湦 10)、方針は「学術上又は由緒上 の価值があると認められるもの」(方針(1))であったとわかる。

(2)では、直接的な記載はないが、解体調査の仕様調書作製上につ いて、「各部につき解体のつど従来の仕様を記録し、併せてその年代 判定を附記する。記録は出来る限り仕事別に区分する。(中略)なお、 写真、図面、現物保存等によりこれを補足する。」とある注 11 。ここの ため、方針(1が継続しつつ、この頃には「仕様の記録として現物保 存」(方針(2) も含んでいたと考えられる。

(3)では、「取り替え等による不用材のうち、現状変更の資料とし たもの及びその他将来重要な参考資料となると思われるもの等は、 防腐・防虫処理を施し、小物は保管箱にまとめるなどしてそれぞれ 説明を付し、小屋裏など適当な場所に保存寸る。(後略)」とある注 12 )。 このため、方針は「現状変更の資料としたもの及びその他将来重要 な参考資料となると思われるもの等」(方針(3)になったとわかる。

ただ、方針(3は「現状変更の資料としたもの」を基調としつつ、 「之の他将来重要な参考資料となると思われるもの」とし、より包 括的な表現であるから、先の 2 方針を包含した考え方一移行したと 推定される。

(4)は先述した現在の方針で、方針(3)がその後もほぼ引き継がれて いるとわかる。このため、方針(3は昭和 49 年に成立し、これが現在 まで適用されていると判断できる。

以上、 3 方針の存在とその変遷を確認した。次に 3 方針と附指定 古材を照合し、その実態を考察したい。

\section{3 附指定の建築部材からみた方針の実態}

\section{1 附指定された建築部材}

正福寺地蔵堂は昭和 9 年に解体修理が竣工したが、その際に刊行 した工事報告書で初めて保存古材の存在を確認できる注13)。しかし、 これ以降の工事報告書では記載内容に粗密がある。また、各地で保 管され膨大な数に上るとみられる保存古材に対し、これまで網羅的 調查はない。そこで、保存古材の全体像を把握するため、既に保護 措置が図られた国宝・重要文化財建造物の附指定古材を用いる。

附指定古材は、先の 3 方針の下に選別され、さらに重要なものと して選別されているから、そこには保存古材の選別方針の実態が具 体的に投影されていると考えられる。

附指定古材には建造物本体と同時指定、またはその後の追加指定
の 2 種があるが、解体修理等の工事で取り外された保存古材を取り 扱うため、今回は後者を対象とする。そこで、官報に掲載された附 指定古材のうち追加指定のものを抽出して作成したのが表 1 である。 行政資料で保存古材の記述が現れるのは、先述の通り昭和 15 年 からで、表 1 に網羅した附指定古材は昭和 19 年以降ではあるが、 その時期的相違は少ないため、この表が保存古材の選別の方針の時 期的特徴を反映している可能性は高い。この表により、件数、内容 及びその推移を把握でき、附指定古材に限られるが、これまで不鮮 明であった保存古材の全体像の一端が明らかになった。

表 1 をみると、昭和 19 年から平成 24 年の間に 67 棟(国宝 20 棟、 重要文化財 47 棟)の附指定古材を確認できる。初めての附指定は No.1-1 二荒山神社本殿の旧本殿棟木断片で、明治 35 年の災害復旧 による屋根修理時に取り外されたものが指定され、「元和五年九月」 の墨書は本殿の建立年代を示寸注 14 )。保存古材の附指定は、昭和 27 年から平成 3 年まで継続的に進められたが、それ以降の増加はあま り見られない。平成 24 年には No.1-67 唐招提寺金堂の保存修理事 業で取り外された旧鴟尾 2 点が金堂創建とその後の修理を物語る建 築部材として附指定されるが注 15)、これ以降の附指定はない。

附指定古材は、建立や修理の年代を示寸墨書等の年記があるもの やこれら年記のない部材に区別できる。部材は 1 点から、複数で構 成されるものがあり、点数が多いものは、No.1-30 三仏寺奥院(投入 堂)の古材 43 点や No.1-32 瑞花院本堂の古瓦 43 枚があり、No.1-11 法隆寺金堂の旧初重軸部(組物を含む) 1 棟が最大規模になる。

\section{2 年記と員数による附指定古材の類型化}

附指定古材の時期的特徵を把握するため、まず附指定古材の性格 と員数から類型化を図り、次に各類型に分類して年代毎の件数を確 認する。最後に 3 方針と照合し、その実態を把握したい。

類型化には、附指定古材の指定理由を考慮しなければならないが、 建造物とは別に独自の指定基準が設けられたことがない。また、保 存古材の追加指定の際の個別の指定理由は幾つか知られるが、全て ではないため、それらも参照できない注16)。しかし、附指定古材は墨 書等の年記の有無及びその性格から、以下の 3 類型に区分できる。 類型 1 建立年代を示寸歴史資料 類型 2 修理年代を示寸歴史資料 類型 3 建立や修理の年代を示寸墨書等がない建築資料 類型 1 は建立の年記を示す附指定古材で、墨書のある棟木や刻銘 のある相輪露盤などが該当する。類型 2 は建立以後の修理の年記が 発見された附指定古材で、軸部や組物、篦書のある瓦などが該当す る。類型 3 は墨書等の年記がない附指定古材で、建立当初の部材、 彫刻などの技法を示すもの、建立以後の修理に伴う部材や現状変更 により取り外された部材などが該当する。

また、各類型は上記の区分のみならず、附指定の員数構成から次 の 2 類型に区分できる。

A 型 単体古材型(員数が 1 点以下の附指定古材)

B 型 古材群型(員数が 2 点以上で群を構成する附指定古材)

$\mathrm{A}$ 型は、極めて重要な価值が認められた部材のみが厳選されて指 定された可能性があり、これに対し、B 型は群として構成される部 材にも重要な価值が認められて指定された可能性がある。

以上、附指定古材の性格と員数構成により区分した各類型の件数 を時期別に示し、3 方針と照合した結果が図 1 である。 
Table 1 Removed Parts by Attachment Designated as National Treasure or Important Cultural Properties (Additional Designation) 表 1 国宝・重要文化財建造物の附指定古材（追加指定）

\begin{tabular}{|c|c|c|c|c|c|c|c|c|c|}
\hline $\begin{array}{l}\text { 番号 } \\
\left(\mathrm{n}_{0}\right)\end{array}$ & 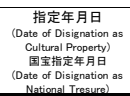 & $\begin{array}{c}\text { 附指定年月 } \\
\text { (Date of Atached } \\
\text { Disigignation) }\end{array}$ & $\begin{array}{l}\text { 所在地 } \\
\text { (Prefecture) }\end{array}$ & 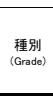 & $\begin{array}{l}\text { 件名 } \\
\text { (Name) }\end{array}$ & $\begin{array}{l}\text { 建箱年代 } \\
\text { (Building Yoar) }\end{array}$ & $\begin{array}{c}\text { 附指定名称 } \\
\text { (Name of Attachement) }\end{array}$ & $\begin{array}{l}\text { 墨書等年記及ひ構成 } \\
\text { (Notes) }\end{array}$ & $\begin{array}{l}\text { 類型 } \\
\text { Typo }\end{array}$ \\
\hline $1-1$ & M41(1908)/8/1 & $\mathrm{S} 19(1944) / 9 / 5$ & 柧木県 & 重文 & 二荒山神社 & 元和5(1619) & 旧本殿棟木断片: 1 籄 & 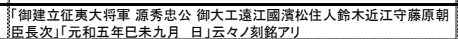 & 1 \\
\hline $1-2$ & $\begin{array}{l}\mathrm{M} 34(1901) / 3 / 27 \\
\mathrm{~S} 27(1952) / 3 / 29\end{array}$ & $\mathrm{~s} 27(1952) / 3 / 29$ & 奈良県 & 国宝 & 祭山寺八䚛 & 天平宝字 $(757-$ & 旧石露盤残欠(宝珠): 1 策 & - & 3 \\
\hline $1-3$ & $\begin{array}{l}\mathrm{M} 33(1900) / 4 / 7 \\
\mathrm{~S} 27(1952) / 3 / 29\end{array}$ & $\mathrm{~S} 27(1952) / 3 / 29$ & 島根県 & 国宝 & 神魂神社本殿 & 天正11(1583) & 心御柱古材: 1 箇 & 正平元年丙戌十一月の記がある & 1 \\
\hline $1-4$ & $\begin{array}{l}\mathrm{M} 35(1(1902) / 7 / 31 \\
\mathrm{S} 27(1952) / 11 / 22\end{array}$ & S27(1952)/11/22 & 京都府 & 国宝 & 宇治上神社拝殿 & 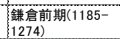 & 栈唐戸：4枚、罴股: 1個 & - & 3 \\
\hline $1-5$ & $\begin{array}{l}\mathrm{M} 34(1901) / 3 / 27 \\
\mathrm{~S} 28(1953) / 3 / 31\end{array}$ & $\mathrm{~S} 28(1953) / 3 / 31$ & 奈良県 & 国宝 & 法隆寺南大門 & 永毫10(1438) & 旧棟木: 1 本 & 上棟永享十年戊午十一月十九日の記がある & 1 \\
\hline $1-6$ & $\begin{array}{l}\mathrm{M} 34(19901) / 3 / 27 \\
\mathrm{M} 28(1953) / 3 / 31\end{array}$ & $\mathrm{~S} 28(1953) / 3 / 31$ & 滋賀県 & 国宝 & 常楽寺三重塔 & 応永 $7(1400)$ & 丸瓦及ひ平瓦:各1個 & 各応永七年五月の記がある & 1 \\
\hline $1-7$ & 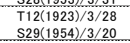 & $s 29(1954) / 3 / 20$ & 兵庫県 & 国宝 & 朝光寺本堂 & 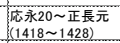 & 廊子震旧欮板 $: 2$ 枚 & 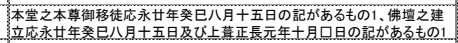 & 1 \\
\hline $1-8$ & $\begin{array}{l}\mathrm{M} 40(1907) / 5 / 27 \\
\mathrm{~S} 27(1952) / 11 / 22\end{array}$ & $\mathrm{~S} 30(1955) / 2 / 2$ & 大分県 & 国宝 & 富責寺大堂 & $\begin{array}{l}\text { F要後期(1086- } \\
184)^{-}\end{array}$ & 旧棟木の部分: 1 本 & 俢造蕗阿弥陀堂一宇文和の記がある & 2 \\
\hline $1-9$ & $\begin{array}{l}\mathrm{M} 34(1901) / 3 / 27 \\
\mathrm{~S} 30(1955) / 2 / 2\end{array}$ & S30(1955)/2/2 & 奈良県 & 国宝 & 法隆寺西円堂 & 建長2 (1250) & 旧小屋組心東: 1 本 & 建長二年夷戊十二月八日の墨書がある & 1 \\
\hline $1-10$ & $\begin{array}{l}\mathrm{M} 30(1897) / 21 / 28 \\
\mathrm{~S} 27(1952) / 3 / 29\end{array}$ & $\mathrm{~S} 33(1958) / 2 / 8$ & 京都府 & 国宝 & 大報思寺本堂 (千本积边堂) & 安貞元(1227) & 旧棟木: 1 本 & 安貞元年蔵次 工亥十二月二六日の記がある & 1 \\
\hline $1-11$ & $\begin{array}{l}\mathrm{M} 30(1897) / 12 / 28 \\
\mathrm{~S} 26(1951) / 6 / 9\end{array}$ & $\mathrm{~S} 34(1959) / 6 / 27$ & 奈良県 & 国宝 & 法隆寺金堂 & 飛鳥(593-709) & 旧初重軸部(組物を含む): 1 構 & - & 3 \\
\hline $1-12$ & $\begin{array}{l}\mathrm{M} 37(1904) / 2 / 18 \\
\mathrm{~S} 36(1961) / 4 / 7\end{array}$ & $\mathrm{~S} 36(1961) / 4 / 27$ & 奈良県 & 国宝 & 菜師寺東院堂 & 弘安8(1285) & 平瓦: 1 枚 & 弘安辛巳の陽刻鎑がある & 1 \\
\hline $1-13$ & $\mathrm{M} 37(1904) / 2 / 18$ & $\mathrm{~S}_{36(1961) / 12 / 27}$ & 兵庫県 & 重文 & 御霊神社本殷 & 文明 $2(1470)$ & 但宮殿㽷: 2 枚 & 各文明或庚寅葴五月廿八日せんくうの記がるる & 1 \\
\hline $1-14$ & $\mathrm{M} 37(1904) / 2 / 18$ & $536(1961) / 12 / 27$ & 兵庫県 & 琹董 & 高壳布神社本殿 & 永正 $10(1513)$ & 旧頭貫: 1 本 & 永正十年八月十九日より初の墨書ある & 1 \\
\hline $1-15$ & $\mathrm{M} 41(1908) / 4 / 23$ & $\$ 36(1961) / 12 / 27$ & 青森県 & 重文 & 最勝院五重塔 & 党文6(1666) & 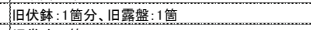 & 旧伏鋉:建立寛文六年五 & \\
\hline $1-16$ & M41(1908)/8/1 & 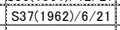 & 质木県 & 重文 & 西明寺粗門 & 明応3(1494) & 㫜巻斗: 1 筍 & 明おうくわん袮元年六月二日の墨書がある & 1 \\
\hline $1-17$ & $T 5(1916) / 5 / 24$ & $s 37(1962) / 6 / 21$ & 㭛本県 & 董文 & 地藏院本黨 & 天文11(1542)頃 & 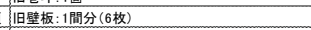 & 命椂三エフ三月三日の墨書がある & 1 \\
\hline $1-18$ & $\mathrm{~S} 4(1929) / 4 / 6$ & $\mathrm{~S} 37(1962) / 6 / 21$ & 山梨県 & 重文 & 武田八幡神社本本殿 & 天文10(1541) & 旧巻斗: 1 䉯 & 天文四年四月日の墨書がある & 1 \\
\hline $1-19$ & M40(1907)/8/28 & 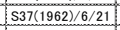 & 山梨県 & 重文 & 長谷寺本黨 & 大永4 $4(1524)$ & 1旧: 11 枚 & 大永四年口口林穜六月の記がある & 1. \\
\hline $1-20$ & $\begin{array}{l}M 41(1908) / 8 / 1 \\
\mathrm{~S} 26(1951) / 6 / 9\end{array}$ & $\mathrm{~S} 42(1967) / 6 / 15$ & 㭛本県 & 国宝 & 東照宮本殿、石の間及ひ择殿 & 䙾永13(1636) & 旧妻戸(本殿): 2 枚 & - & 3 \\
\hline $1-21$ & $\begin{array}{l}M 30(1937) / 21 / 28 \\
S 27(1952) / 3 / 29\end{array}$ & S42(1967)/6/15 & 奈良県 & 国宝 & 興福寺北円堂 & 承元 $4(1210)$ & 旧内陳小壁: 8 組 & - & 3 \\
\hline $1-22$ & $M 40(1907) / 5 / 27$ & $\$ 42(1967) / 12 / 11$ & 兵庫県 & 重文 & 䳽林寺鏩楼 & $\sqrt{\mathrm{E}}$ 永14(1407) & 旧小屋村: 1個 & 修理元禄十一戌寅年三月八日の記がある & 2 \\
\hline$\frac{25}{1-23}$ & $M 40(1907) / 5 / 27$ & $S 42(1967) / 12 / 11$ & 香川県 & 箽文 & 明王寺积迦堂 & 天文2(1533) & 丸瓦及ひ平瓦: 23 枚 & 大永八年の韽書のあるもの19、その他の筐書があるもの4 & 1 \\
\hline $1-24$ & $M 40(1907) / 8 / 28$ & $\$ 42(1967) / 12 / 11$ & 奈良辱 & 重文 & 海童王寺経蔵 & 正応元(1288) & 但向洋手挗:2個 & & 3 \\
\hline $1-25$ & $\begin{array}{l}\mathrm{S} 13(1938) / 7 / 4 \\
\mathrm{~S} 28(1953) / 11 / 14\end{array}$ & S46(1971)/3/11 & 岡山県 & 国宝 & 旧閉谷学校講堂 & 元禄14(1701) & 壁書: 1 枚、丸瓦: 1枚 & 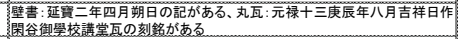 & 1 \\
\hline $1-26$ & 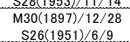 & $S 46(1971) / 6 / 22$ & 奈良県 & 国宝 & 唐招提寺金堂 & 奈良(710-793) & 旧部材: 22 枚 & 旧内陣天井支輪板4、旧内陣天井板6、旧軒支輸板12 & 3 \\
\hline \begin{tabular}{|c|}
$1-27$ \\
\end{tabular} & $\begin{array}{l}\mathrm{M} 300(1897) / 12 / 28 \\
526(1951) / 6 / 28\end{array}$ & S47(1972)/5/15 & 京都府 & 国宝 & 平等院風凰堂中堂 & 天喜元(1053) & 旧板屝: 8 枚、旧風凰棟飾: 1 対 & 旧板赫: 上品中生、上品下生、中品上生、下品上生各2枚 & 3 \\
\hline $1-28$ & $\begin{array}{l}529(1954) / 9 / 17 \\
5\end{array}$ & $548(1973) / 11 / 29$ & 埲岡昷 & 重文 & 油山圭山門 & 藏治2(1659) & 能: 2 個 & & 3 \\
\hline $1-29$ & $\begin{array}{l}\mathrm{M} 41(1908) / 8 / 1 \\
\mathrm{~S} 26(1951) / 6 / 9\end{array}$ & S52(1977)/6/27 & 栃木県 & 国宝 & 東照宮隄明門 & 䙾永13(1636) & 旧天井板: 2 枚 & - & 3 \\
\hline $1-30$ & $\begin{array}{l}\mathrm{M} 37(1904) / 2 / 18 \\
\mathrm{~S} 27(1952) / 3 / 29\end{array}$ & S52(1977)/6/27 & 烏取県 & 国宝 & 三仏寺奥院(投入堂) & $\begin{array}{l}\text { 平安後期(1086- } \\
184 \text { ) }\end{array}$ & 古材: 43 点 & 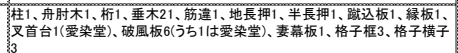 & 3 \\
\hline $1-31$ & $\begin{array}{c}\text { M30(1897)/12/28 } \\
\text { S26(1951)/6/9 }\end{array}$ & S53(1978)/5/31 & 岩手県 & 国宝 & 中尊寺金色堂 & 天治元 (1124) & 1日組高棝:6組、古材: 6点、1日飾金具: $:$ 点 & 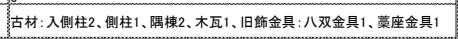 & 3 \\
\hline $1-32$ & $M 40(1907) / 8 / 28$ & $\mathrm{~S} 55(1980) / 5 / 31$ & 奈良県 & 重文 & 瑞花院本堂 & 嘉吉3(1443) & 古瓦:43枚 & 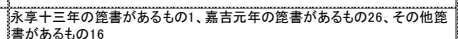 & 1 \\
\hline $1-33$ & $T 5(1916) / 5 / 24$ & $\$ 55(1980) / 5 / 31$ & 奈良県 & 重文 & 御賈神社本殿 & 文明4(1472) & 旧天井板: 3 枚 & 原寸引付圆がある & 3 \\
\hline $1-34$ & $\mathrm{~T} 11(1922) / 4 / 13$ & S55(1980)/5/31 & 奈良県 & 重文 & 圆福寺本堂 & 心安4(1371) & 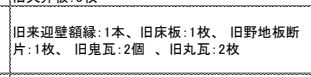 & 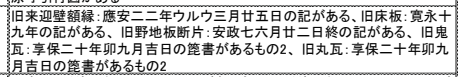 & 1 \\
\hline $1-35$ & $\mathrm{~T} 14(1925) / 4 / 24$ & $\mathrm{~S} 55(1980) / 5 / 31$ & 奈良県 & 重文 & 不動院本堂 & 文明15(1483) & 1日襄甲: 2 枚 & 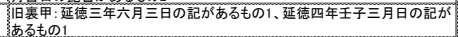 & 2 \\
\hline $1-36$ & $\operatorname{M44(1911)/4/17}$ & $\mid s 55(1980) / 12 / 18$ & 奈良県 & 重文 & 室生寺御影堂 & $\begin{array}{l}\text { 空町前期(1333- } \\
\text { 1392) }\end{array}$ & 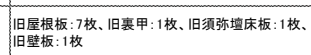 & 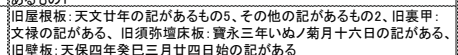 & 2 \\
\hline $1-37$ & $\mathrm{~S} 34(1959) / 6 / 27$ & $\mathrm{~s} 55(1980) / 12 / 18$ & 奈良県 & 重文 & 南法華寺礼堂 & 明応6年 (1497) & 旧野地板: 2枚、1 旧出析知木: 1 個、旧鬼瓦: 2個 & 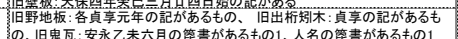 & 2 \\
\hline $1-38$ & $\mathrm{~T} 12(1923) / 3 / 28$ & $\mid \mathrm{s} 56(1981) / 6 / 5$ & 滋賀県 & 重文 & 八幅社本殿 & 文禄 5(1596) & 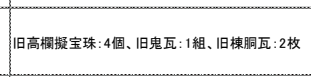 & 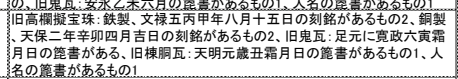 & 1 \\
\hline $\mid$ & $\mathrm{S} 24(1949) / 2 / 18$ & $\mathrm{~S} 56(1981) / 6 / 5$ & 滋賀県 & 重文 & 志那神社本殿 & 永仁 6 (1298) & 旧棟木の部分: 1 個、古材: 5 点 & 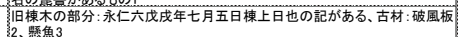 & 1 \\
\hline $1-40$ & M37(1904)/2/18 & $S 56(1981) / 6 / 5$ & 洋賀県 & 重文 & 苗村神社楼門 & 大永2(1522) & 古材: 2 点 & 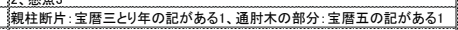 & 2 \\
\hline $1-41$ & $\mathrm{M} 35(1902) / 4 / 17$ & $556(1981) / 6 / 5$ & 羍良県 & 䜺文 & 般若寺十三熏塔 & 䢖喜50 & 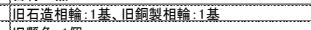 & 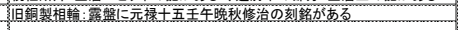 & \\
\hline $1-42$ & $\mathrm{M} 37(1904) / 2 / 18$ & $556(1981) / 6 / 5$ & 奈良䭔 & 重文 & 不退寺南門 & 正和6 & 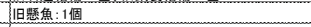 & & 3 \\
\hline $1-43$ & $\mathrm{M} 41(1908) / 4 / 23$ & $556(1981) / 6 / 5$ & 奈良県 & 重文 & 不退寺塔倠 & 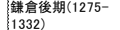 & 古材 $: 7$ 点 & 尾垂木6、心柱の部分1 & 3 \\
\hline $1-44$ & $S 22(1947) / 2 / 26$ & S56(1981)/6/5 & 奈良県 & 重文 & 福智院本堂 & 建仁3(1203) & 旧軒平瓦: 1枚 & |旧軒平瓦:元文五年五月申五月吉日の筮書がある & 2 \\
\hline $1-45$ & $\mathrm{~T} 2(1913) / 4 / 14$ & $\$ 57(1982) / 2 / 16$ & 浩筫県 & 重文 & 腾部神社本殿 & 明応6(1497) & 但軒付留甲: 1 個 & 天明八年三月申三月吉旺 & 2 \\
\hline $1-46$ & $\mathrm{~T} 14(1925) / 4 / 24$ & $\mathrm{~s} 57(1982) / 2 / 16$ & 滋賀県 & 重文 & 飯道神社本殿 & 慶安2(1649) & 古材: 3 点 & 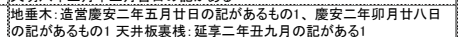 & 1 \\
\hline $1-47$ & M35(1902)/7/31 & $\mathrm{S} 58(1983) / 1 / 7$ & 湴賀県 & 重文 & 圆满院唇殿 & 元和5 (1619) & 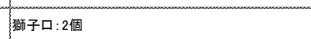 & 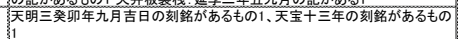 & 2 \\
\hline $1-48$ & $\mathrm{~T} 13(1924) / 4 / 15$ & $558(1983) / 1 / 7$ & 滋賀県 & 重文 & 梪所神社表門 & 明厢元 (1655) & 旧吸付栈: 2 本 & 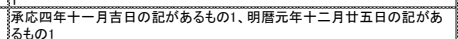 & 1 \\
\hline $1-49$ & $\mathrm{~S} 28(1953) / 3 / 31$ & $558(1983) / 1 / 7$ & 滋䝷県 & 重文 & 圆光寺本堂 & 康元2(1257) & 䰠瓦:2個 & 宝永元甲申ノ天十月吉日の刻路があるもの1 & 2 \\
\hline $1-50$ & M42(1909)/4/5 & S59(1984)/5/21 & 京都府 & 重文 & 大德寺法堂 & 窅永13(1636) & 旧直板: 2 枚、旧土居草板: 3 枚 & 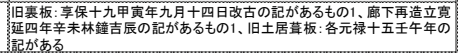 & 2 \\
\hline $1-51$ & M42(1909)/4/5 & S59(1984)/5/21 & 京都府 & 重文 & 大德寺山門 & 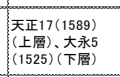 & 旧土居草板: 4枚、鬼瓦: 3個 & 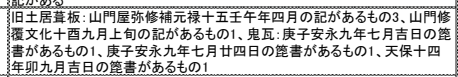 & 2 \\
\hline $1-52$ & $S 46(1971) / 12 / 28$ & $S 60(1985) / 5 / 18$ & 岐皇県 & 重文 & 桑原家住宅(岐皇県養老郡上石津町) 主屋 & 章保19(1734) & 旧天井篻緑: 2 本 & 各莌政十二年の記かある & \\
\hline $1-53$ & 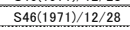 & $\begin{array}{l}\mathrm{s} 60(1985) / 5 / 18 \\
\end{array}$ & $\begin{array}{ll}\text { 伖皇県 } \\
\end{array}$ & 重文 & 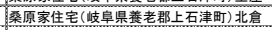 & 䙾保2(1742) & 旧鬼瓦: 1 固 & 嘉永五年子十一月九日出来の䇫書がある & \\
\hline $1-54$ & $\mathrm{M} 32(1899) / 4 / 5$ & 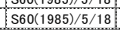 & 京都府 & 重童 & 南觯寺三門 & 䙾永5(1628) & 古瓦: 7 枚 & 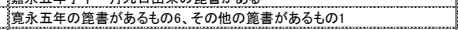 & 1 \\
\hline $1-55$ & $\mathrm{~T} 12(1923) / 3 / 28$ & S61(1986)/12/20 & 京都府 & 重文 & 十八神社本殿 & 長享元 (1487) & 旧軒付板: 1 枚 & 家根替聶替天保七年の記がある & \\
\hline $1-56$ & $\mathrm{~T} 11(1922) / 4 / 13$ & $\mathrm{~S} 61(1986) / 5 / 24$ & 京都府 & 重文 & 天球院本堂 & 寛永(1624-1643) & 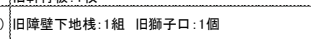 & 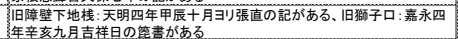 & 2 \\
\hline $1-57 \mid$ & $\mathrm{S} 42(1967) / 6 / 15$ & $\mathrm{~S} 61(1986) / 5 / 24$ & 京都府 & 重文 & 触梅院本堂 & 慶長 $9(1604)$ & 旧壁下地板: 1 枚、旧緣框: 1 本、古村: 25 点 & 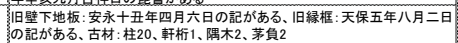 & 2 \\
\hline $1-58$ & $S 48(1973) / 6 / 2$ & $S 61(1986) / 12 / 20$ & 奈良県 & 重文 & 大峰山寺本堂 & 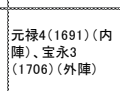 & 1日銅丸瓦: 26 枚、1旧銅丸瓦: 10 枚 & 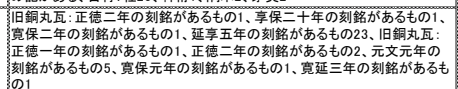 & 2 \\
\hline $1-59$ & $\mathrm{~S} 37(1962) / 6 / 21$ & $\mathrm{~S} 62(1987) / 6 / 3$ & 京都府 & 重文 & 興臨院本堂 & $\begin{array}{l}\text { 天文 永椂 } \\
(15322-1599)\end{array}$ & 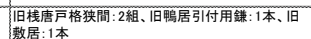 & 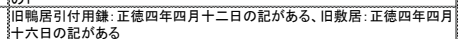 & 2 \\
\hline $1-60$ & $M 40(1907) / 8 / 28$ & $s 63(1988) / 1 / 13$ & 京都府 & 重文 & 雙栗神社本殿 & & 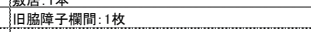 & & \\
\hline $1-61$ & $\mathrm{~S} 12(1937) / 7 / 29$ & $\mathrm{~S} 63(1988) / 1 / 13$ & 京都府 & 重文 & 春日神社本殿 & 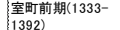 & 旧向抹頭貫：1組 & - & 3 \\
\hline $1-62$ & $\mathrm{~T} 12(1923) / 3 / 28$ & $S 63(1988) / 1 / 13$ & 京都府 & 重文 & 神童寺本堂 & $\sqrt{152}$ 永13(1406) & 旧鬼瓦:2固 & 各文化三年寅九月の花書がある & 2 \\
\hline $1-63$ & $\mathrm{~T} 2(1913) / 4 / 14$ & H1(1989)/5/19 & 京都府 & 重文 & 萬楅寺天王殿 & 寞文8(1668) & 旧土居惪板: 1 板 & 寘文八蔵の記がある & 1 \\
\hline $1-64$ & $M 32(1899) / 4 / 5$ & H1(1989)/5/19 & 京都府 & 重文 & 岩船寺三重塔 & 嘉吉2(1442) & 隅木受飾束: 1 1 個 & - & 3 \\
\hline $1-65$ & S52(1977)/1/28 & H3(1991)/5/31 & 新渴県 & 重文 & 若林家住宅(新渴県村上市三之町) & 淜和6(1769) & 旧床板: 1 枚 & 式台板図 & 3 \\
\hline $1-66$ & $M 40(1907) / 8 / 28$ & $H 10(1998) / 12 / 25$ & 山梨県 & 重文 & 隻八幖神社本殿 & 永正16(1519) & 旧壁板(永正十六年)：5板 & $E$ & 1 \\
\hline $1-67$ & $\begin{array}{c}\text { M30(1897)/12/28 } \\
\text { S26(1951)/6/9 }\end{array}$ & $\mathrm{H} 24(2012) / 7 / 9$ & 奈良県 & 国宝 & 唐招提寺金堂 & 奈良(710-793) & 旧舀尾: 2 個 & 当初のもの1、元亨三年の記があるもの1 & 2 \\
\hline
\end{tabular}




\section{3 各類型の件数の推移とその意味}

各類型の件数の推移は、昭和 50 年代半ばまでは類型 1 が多く、

それ以降は類型 2 と類型 3 の増加の傾向を確認できる。

類型 1 では $\mathrm{A}$ 型が昭和 19 年から現れ、昭和 30 年代後半まで増 加傾向があるが、その後の変化は見られないのに対し、B 型は昭和 28 年に現れ、昭和 50 年代後半まで緩やかな増加がみられる。

類型 2 では、A 型が昭和 30 年に現れ、B 型は昭和 55 年に遅れて 現れる。いずれも増加がみられるのは昭和 50 年代半ば以降である。

類型 3 では、 $\mathrm{A}$ 型及び $\mathrm{B}$ 型はいずれも昭和 27 年に現れるが、 $\mathrm{A}$ 型の本格的な増加は昭和 50 年代後半にみる。B型は昭和 40 年代後 半から昭和 50 年代後半にかけての増加がみられる。いずれの類型 も昭和 50 年代半ばから B 型が増加することが特徵である。

以上の各類型の推移を先の 3 方針と照合し、考察を巡らせたい。 方針(1)が適用された昭和 19 年から昭和 48 年の時期は、類型 1 が 増加する時期である。この類型には、No.1-3 神魂神社本殿の心御柱 古材 1 箇やNo.1-5 法隆寺南大門の旧棟木 1 本など、軸部、小屋組、 組物の部材で建立年代を示す墨書のあるものや、No.1-23 明王寺釈 迦堂の丸瓦及び平瓦 23 枚など、建立年代を示す䇛書のある瓦など がみられる。これらは解体修理で取り外された部材であるが、墨書 等の年記がある点で特徴付けられ、方針(1)「学術上又は由緒上の価 值があると認められるもの」の主な対象になったと考えられる。

方針(2)が現れる昭和 31 年から昭和 48 年の時期は、類型 3 が現れ る時期とほぼ重なる。No.1-20 東照宮本殿、石の間及び拝殿の旧妻 戸(本殿) 2 枚は当初の蒔絵を残す部材注 17)で、No.1-26 唐招提寺金堂 の旧部材 22 枚は当初の彩色を残す部材注 18)である。これらから、墨 書等の年記はないが、建立時の貴重な部材が、方針(2)「仕様の記録 として現物保存」の主な対象になったと考えられる。

方針(3)が適用された昭和 49 年以降は、類型 2 と類型 3 が急激に 増加した時期である。類型 2 のうち、No.1-36 室生寺御影堂の旧屋
根板は、昭和 50 年の現状変更で、屋根を檜皮莫から厚板段莫に復 旧した際の根拠資料である注 19)。また、No.1-40 苗村神社楼門の古材 2 点は、昭和 54 年の現状変更で、楼門上層の構造を建立当初の姿に 復旧した際、撤去した部材の一部注 20)で、こうした部材が方針(3の 示す「現状変更の資料としたもの」の対象になったと考えられる。

一方、類型 3 にはNo.1-30 三仏寺奥院(投入堂)の古材 43 点やNo.143 不退寺塔婆の古材 7 点など、名称を「古材」そのものとし、古材 群の附指定が開始されるのが特徴である。また、No.1-57 衡梅院本 堂の古材 25 点のように、前身建物から転用された部材を含んでい るのもあり注 21)、これらが方針(3)の示す「その他将来重要な参考資 料となると思われるもの等」の主な対象になったと考えられる。

なお、昭和 49 年以降では類型 1 の微増も確認できる。このこと から、方針(3)が方針(1)と方針(2)を包含した考え方であるという先の 推定も裏付けられた。また、昭和 49 年の方針(3) の移行は、A 型 から B 型への移行時期とほぼ重なることから、附指定古材では方針 の段階的な拡充に伴い、古材群型へ移行したことも明らかになった。

以上、附指定古材の各類型を 3 方針と照合した結果、方針(1)が類 型 1 、方針(2)が類型 3 、方針(3)が類型 2 と類型 3 にそれぞれ対応関 係にあることを指摘でき、全保存古材からみた方針の実態は依然と して不明であるが、附指定古材に基づく方針の実態は鮮明になった。

ここで方針(3)現在の運用状況を確認しておきたい。附指定古材 がなくなった平成 24 年以降刊行の工事報告書 (平成 24 年 1 月から 令和 3 年（2021）3 月）に掲載された 330 棟の建造物で保存古材を 確認できたものを取り纏めたのが表 2 である

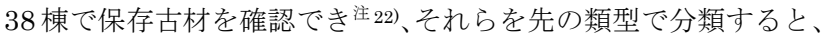
類型 1 の B 型が 2 棟、類型 2 の B 型が 4 棟、類型 3 の $\mathrm{A}$ 型が 1 棟、 類型 3 の $\mathrm{B}$ 型が 31 棟となる。修理工事を経た全ての建造物の把握 ではないが、把握できたものは、類型 2 と 3 が多数派を占めること から、保存古材に基づく実態においても方針(3の継続を確認できた。

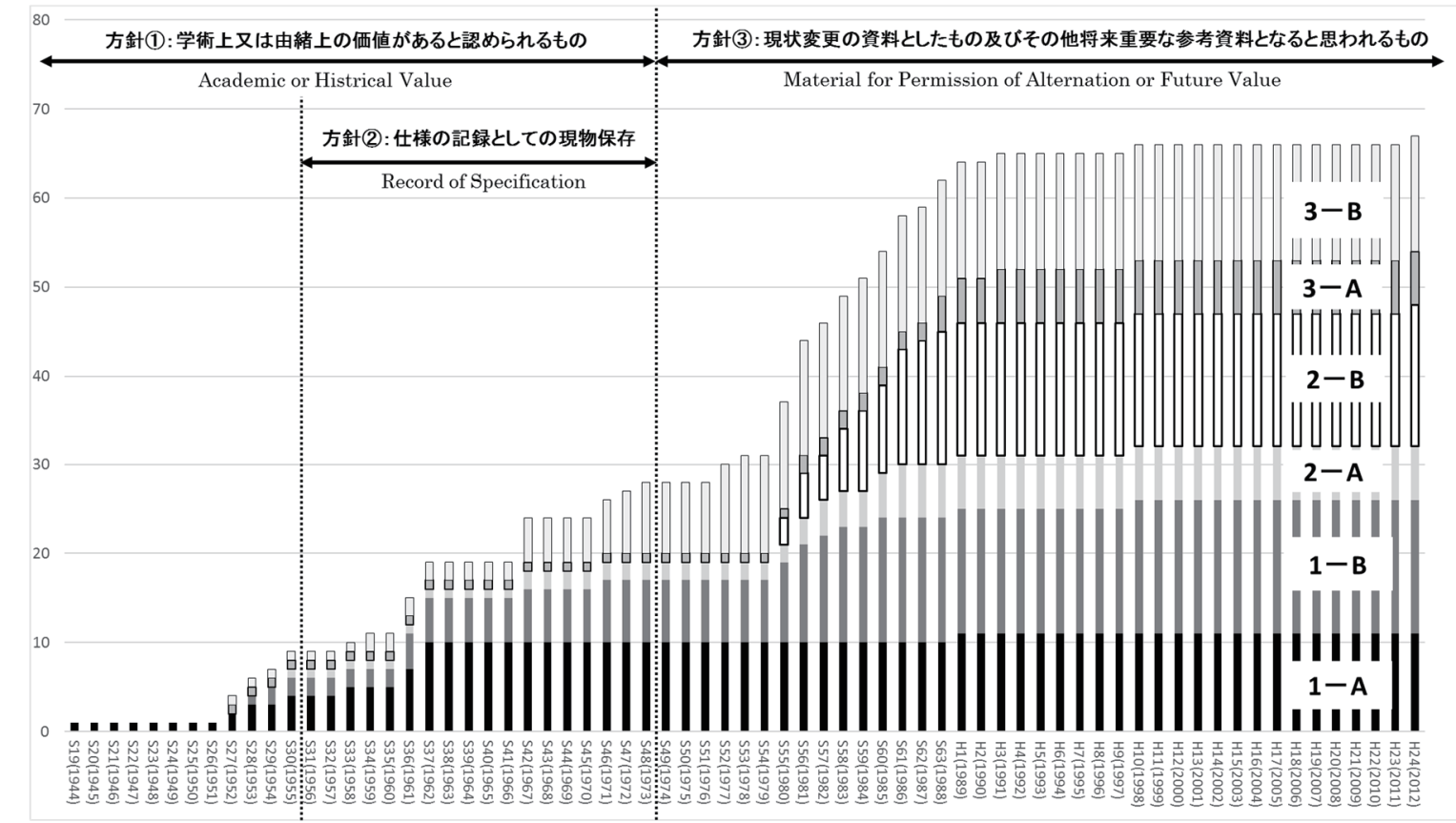

Fig.1 Trend of 6 Types of Removed Parts Compared with 3 Selection Criteria 
Table 2 Removed Parts Recorded by Conservation Report for Architectural Cultural Properties (Jan. 2012-Mar. 2021) 表 2 修理工事報告書における保存古材（平成 24 年 1 月一令和 3 年 3 月）

\begin{tabular}{|c|c|c|c|c|c|c|c|c|c|}
\hline \begin{tabular}{|l|}
$\begin{array}{l}\text { 番 } \\
\text { (No.) } \\
\end{array}$ \\
\end{tabular} & \begin{tabular}{|c|} 
所在地 \\
(Prefecture)
\end{tabular} & 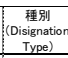 & $\begin{array}{c}\text { 件名 } \\
\text { (Name of Disignation) }\end{array}$ & $\begin{array}{c}\text { 保存古村点数 } \\
\text { (Number of of } \\
\text { Removed Parts) }\end{array}$ & $\begin{array}{c}\begin{array}{c}\text { 構成 } \\
\text { (Notes) }\end{array} \\
\end{array}$ & $\begin{array}{l}\text { 類型 } \\
\text { (Type }\end{array}$ & 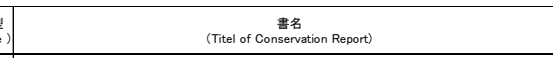 & $\begin{array}{c}\text { 発行所名 } \\
\text { (Publishing Office) }\end{array}$ & \begin{tabular}{|c} 
発行年月 \\
(Month and Year of \\
Publication)
\end{tabular} \\
\hline $2-1$ & 福井県 & 重文 & 須波阿㥧疑神社本殿 & 62 & 木材 62 点 (昭和25年竣工の解体格理時の保存古材) & \begin{tabular}{l|l}
3 & $B$ \\
\end{tabular} & B 重要文化財須波阿須疑神社本殿保存格理工事䢁告書 & 宗教法人須波阿須疑神社 & 2012.3 \\
\hline $2-2$ & 满賀県 & 重文 & 滕部神社本殿 & 19 & 幹丸互11枚、軒平互8枚 & 3 & 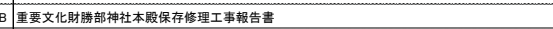 & 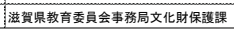 & 2012.2 \\
\hline $2-3$ & 東京都 & 重文 & 寛永寺旧本坊表門(黑門) & 189 & 木材 157 点、瓦4枚(移築年代篦意あり)、金物28点 & $2 \mathrm{E}$ & 8 重要文化財寞永寺旧本坊表門（黑門）保存修理工事報告韋 & 宗教法人輪王寺 & 2012.2 \\
\hline $2-4$ & 東京都 & 重文 & 護国寺月光殿 (旧日光院客尉) & 623 & 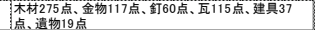 & 3 E & 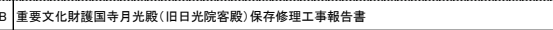 & 宗教法人丳国寺 & 2014.1 \\
\hline 2-5 & 山梨県 & 重文 & 䔍眼寺本堂 & 580 & 木杜580点 & 3 E & 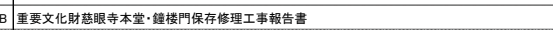 & 宗教法人菣眼寺 & 2014.1 \\
\hline $2-6$ & 山梨県 & 重文 & 菻眼寺䀫楼門 & 139 & 木村 139 点 & 3 E & 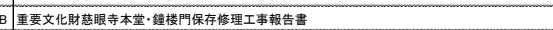 & 同上 & 同上 \\
\hline $2-7$ & 湾筫景 & 重文 & 宇和宮神社本殿 & 1 & 木林1点 & $3 \mathrm{~A}$ & 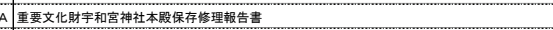 & 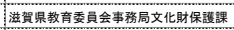 & 2014.3 \\
\hline $2-8$ & 山口県 & 重文 & 旧下関英国領事館本館 & 23 & 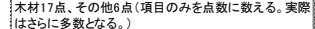 & 3 & 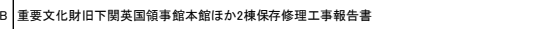 & 下関市 & 2014.3 \\
\hline $2-9$ & 山口県 & 重文 & 旧下関英国領事帥附属屋 & 4 & 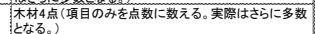 & 3 & B 同上 & 同上 & 同上 \\
\hline $2-11$ & 和歌山県 & 重文 & 琴人浦温山荘浜座数 & 217 & 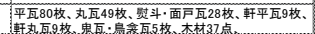 & 3 E & B 重要文化盰琴ノ浦温山乼浜座戨にか2梾修理工事軗告書 & 公益財团法人琴八浦温山荘 & 2015.3 \\
\hline $2-12$ & 和歌山県 & 重文 & 琴人浦温山萑冠木門 & 31 & 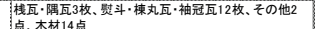 & 3 & B 同上 & 同上 & 同上 \\
\hline $2-13$ & 和歌山県 & 重文 & 琴今浦温山在正門 & 2 & 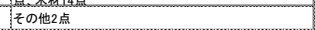 & 3 B & B 同上 & 同上 & 同上 \\
\hline $2-14$ & 愛媇県 & 重文 & 如法寺仙殿 & 35 & 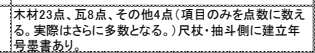 & 1 . & 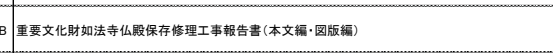 & 宗教法人如法寺 & 2015.3 \\
\hline $2-15$ & 奈良景 & 重文 & 䍛庶奥院本堂 & 73 & $\begin{array}{l}\text { 年树 } 73 \text { 点 } \\
\end{array}$ & $3=$ & 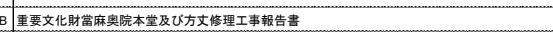 & 奈良県教育委員会 & 2015.12 \\
\hline $2-16$ & 奈良県 & 重文 & 常底奠院方丈 & 2 & 木林2 点 & 3 B & B同上 & 同上 & 同上 \\
\hline $2-17$ & 東京都 & 重文 & 武家屋敨門 & 181 & 木材 11 点、金具類 170 点 & 3 & B 重要文化財武家屋数門移筑工事軚告韋 & 学校法人山胡学圈 & 2016.10 \\
\hline $2-18$ & 神奈川県 & 重文 & 宝城坊本堂 & 21 & 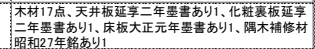 & 2 & B 重要文化財宝城坊本堂保存修理工事教告書 & 宗教法人宝城坊 & 2017.2 \\
\hline $2-21$ & 長野是 & 重文 & 神明社㗇殿 & 12 & 木材 12 点 & 3 B & $\mathrm{B}$ 同上 & 同上 & 同上 \\
\hline $2-22$ & 長野辱 & 重文 & 神明社神亲殿 & 18 & 木材18点 & 38 & B同上 & 同上 & 同上 \\
\hline $2-23$ & 長野暴 & 重文 & 神明社聚台 & 5 & 木林5 点 & 3 B & $\mathrm{B}$ 同上 & 同上 & 同上 \\
\hline $2-24$ & 京都府 & 国宝 & 光明寺二王門 & 115 & 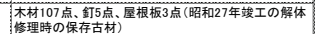 & 3 E & B 国宝光明寺二王門修理工事辄告書 & 京都腑教育庁指導部文化財保誰漅 & 2019.3 \\
\hline $2-25$ & 京都府 & 国宝 & 平等院俨周堂 & 260 & 木材152点. 金具108点 & 3 E & B 国宝平等院風風堂平成修理软告書 & 宗教法人平等院 & 2019.3 \\
\hline $2-26$ & 奈良県 & 国宝 & 法隆寻中門 & 6 & 木材 6 点(明治34年变工の解体修理時の保存古材) & 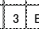 & B 国宝法浲寺中門ほか2梀格理工事䢁告韋 & 奈良県教育委㒬会 & 2019.3 \\
\hline $2-27$ & 長野県 & 重文 & 瘐内家住宅 & 24 & 木材 24 点 & 3 B & B 重要文化盰堀内家住宅ほか心楝保存修理工事辄告韋 & 㿋内建 & 2019.3 \\
\hline $2-28$ & 大服府 & 重文 & 火走神社搢社幸神社本殿 & 5 & 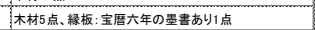 & 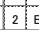 & B 重要文化盰火走神社儤社幸神社本殿 保存修理工事䡑告韋 & 宗教法人火走神社 & 2019.10 \\
\hline $2-29$ & 京都府 & 重文 & 知思院本堂 & 46 & 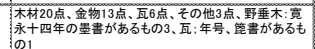 & 1 (1) & 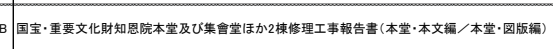 & 京都府教育庁指導部文化盰保設維 & 2019.11 \\
\hline $2-30$ & 奈良景 & 重文 & 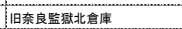 & 5.594 & 瓦5.558点、建具4点、木材3点、煉瓦22点、その他7点 & 3 E & 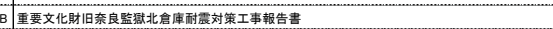 & 旧秦良監镜保存活用株式会社 & 2020.2 \\
\hline $2-31$ & 神奈㝸 & 国宝 & 宝葴寺覞音堂 & 1.071 & 木材了点、眼刻、068点 & 3 & B & 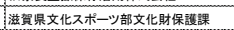 & 2020.7 \\
\hline $2-32$ & 群馬県 & 国宝 & 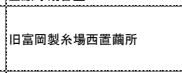 & 276 & 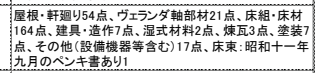 & 2 & 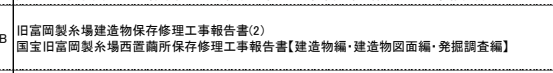 & 富岡市·富岡市教育委員会 & 2020.8 \\
\hline $2-33$ & 能本県 & 重文 & 阿鮛神社一の神殿 & 2 & 木材1 1 点、彫刻1点 & 3 E & 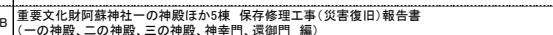 & 宗教法人阿蘇神社 & 2020.10 \\
\hline $2-34$ & 能本県 & 重文 & 阿蘇神社二の神殿 & 2 & 木林 2 点 & 3 B & B 同上 & 同上 & 同上 \\
\hline $\begin{array}{l}\mid-345 \\
2-35 \\
\end{array}$ & 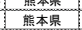 & 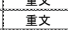 & 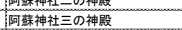 & $\frac{2}{5}$ & 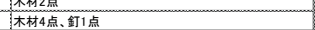 & 3 & 最上 & 同上 & 同上 \\
\hline $2-36$ & 能本県 & 重文 & 阿蘚神社神幸門 & 3 & 木林 3 点 & 3 & B同上 & 同上 & 同上 \\
\hline $2-37$ & 能本県 & 重文 & 阿独神社遥御門 & 2 & 木林2 & 3 & B同上 & 同上 & 同上 \\
\hline $2-38$ & 愛知県 & 重文 & 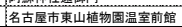 & 111 & 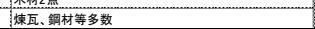 & 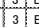 & 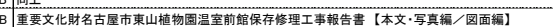 & 名古屋宣 & 2021.3 \\
\hline
\end{tabular}

一方、方針がない昭和 15 年以前は、附指定古材もないため、これ らに基づく実態把握を進めることができない。だが、最初期の解体 修理における保存古材の実例や工事報告書から、保存古材の取り扱 いの様相が幾らか知られる。

\section{4. 昭和 15 年以前の保存古材の取り扱い}

\section{1 解体修理における保存古材の保管の開始}

明治 30 年に始まる古社寺保存法における最初期の解体修理では、 新薬師寺本堂、法起寺三重塔及び唐招提寺金堂の 3 例が知られる。 新薬師寺本堂は明治 31 年竣工の解体修理で、正面の切妻造礼堂、 内部では周囲の間仕切、身舎天井等が撤去され、須弥壇の前面が復 旧された。破風板 2 枚と大斗 1 個がこの時の保存古材として保管さ れている注23)。

法起寺三重塔は、明治 31 年竣工の解体修理で、主に基壇修理の 石積の積替、初重の床の及び登り縁の撤去、扉口及び側迴りの地長 押の整備等が実施された。切断された心柱の断片(三丁継の下方部) が、この時の保存古材として保管されている注24)。

唐招提寺金堂は明治 32 年竣工の解体修理で、小屋組を卜ラス構 造に改変、入側柱から内陣大虹梁下の頬杖の撤去等が実施された。 旧内陣天井支輪板 4 枚、旧内陣天井板 6 枚、旧軒支輪板 12 枚(No.126 参照)がこの時の保存古材として保管されている注 25)。

このように僅か 3 例であるが、最初期の解体修理から保存古材の
保管の開始を確認できる。

\section{2 工事報告書にみる保存古材の記録の開始}

工事報告書で初めての保存古材は、先述の通り昭和 9 年に解体修 理が竣工した正福寺地蔵堂で確認でき、下層の巻斗、飛檐棰、地棰、 飛檐隅木、枠肘木、弓格子を各 1 個、上層の枠肘木 2 個、飛檐棰、 地棰、茅負切各 1 個、化粧裏板、巻斗各 2 個の合計 15 個を「保存 古材目録」として掲載する注 26)。

次の事例は、昭和 10 年に解体修理が竣工した法隆寺食堂及び食 堂で、小屋組解体時に土居桁、野垂木、その他小屋組材に転用して あった破風板、茅負、垂木等の古材 28 点が発見された。このうち、 垂木 1 本、食堂及び細殿の旧破風板断片 7 個、食堂の旧茅負 2 個、 旧木負 1 個、計 11 個が選別され、小屋組で保管される注 27)。

昭和 12 年に解体修理が竣工した興隆寺本堂の工事報告書では、 「不再用古材は工事中、一定の場所に整理し、工事俊成後 、就中價 值あるものは寺院に収納し新補型板其他工事關係品は本堂小屋内に 納めた。とあり注28)、その保管を示寸記載がある。

また、昭和 13 年に解体修理が竣工した石津寺本堂の工事報告書 でも、「発見せる古材の内修理再用し得るものは使用し然らざるもの は本堂小屋裏内に保存する事とした」とあり注 29)、同じく保管を示 す記載を確認できる。

このように昭和 9 年頃から工事報告書への保存古材の記録の開始 を確認できる。 


\section{3 昭和 15 年以前の保存古材の取り扱いの様相}

文化財建造物の保存修理事業への考え方を示寸行政資料では、国 以外では、京都府の「古社寺建造物修理規定」(明治 31 年 7 月 7 日 付京都府令第 57 號）注30)、滋賀県の「社寺建造物修理及び会計規則」 (明治 31 年 2 月 3 日付縣令第十四號) 注 31 及び「特別保護建造物修 理方針」(明治 36 年 8 月 1 日付) 注 32 ) が知られる。だが、いずれも保 存古材に関する記載は全く見当たらず、これらに基づく保存古材の 取り扱いの様相は判明しない。

しかし、保存古材の実例を通して、日本の文化財建造物の保存修 理では、不再用部材の中から一部を選別して古材として保管すると いう取り扱いが、最初期の解体修理から存在することを確認できた。 また、昭和 9 年頃に工事報告書への保存古材の記録を開始したこと も判明し、詳細な実態は不明であるが、方針が現れる昭和 15 年に 至るまでの保存古材の取り扱いの様相を把握できた。

\section{5. 結論}

以上、本稿では行政資料に現れる保存古材を選別する際の方針に 着目して、その存在の有無と变遷を明らかにした上で、附指定古材 に基づきその実態を把握した。

方針は、昭和 15 年に初めて行政資料に示され、方針(1)「学術上又 は由緒上の価值があると認められるもの」となり、その後、昭和 31 年に方針(2)「仕様の記録として現物保存」を含みつつ、さらに昭和 49 年にこれまでの方針を包含して、方針(3)「現状変更の資料とした もの及びその他将来重要な参考資料となると思われるもの等」とし て成立したことを確認でき、段階的に拡充した方針の変遷が明らか になった。

また、附指定古材の各類型の推移と 3 方針を照合した結果、方針 (1)は「建立年代を示寸歴史資料」、方針(2)は「建立や修理の年代を示 す墨書等がない建築資料」、方針(3は「修理年代を示寸歴史資料」と 「建立や修理の年代を示寸墨書等がない建築資料」にそれぞれ対応 関係にあることを確認し、附指定古材に限定されるものの、これま で不鮮明であった方針の実態が明らかになった。さらに附指定古材 は方針の段階的な拡充に伴い、昭和 50 年代半ばには員数構成が単 体古材型から古材群型へ移行したことも確認した。

これらの結果に前節で確認した昭和 15 年以前の様相を加え、各 時代における保存古材の取り扱いを整理すると、古社寺保存法時代 では保存古材の保管の開始、国宝保存法時代では工事報告書への記 録、行政資料での方針の明示及び保存古材の附指定の開始、文化財 保護法時代では方針の段階的な拡充とこれに伴い、附指定古材の単 体古材型から古材群型への移行として捉えることができた。これら より、日本の文化財建造物における保存古材の取り扱いの変遷を全 体的に見通すことが可能になった。

さらに、昭和 30 年代から 40 年代にかけての方針の段階的な拡充 の時期は、先学が指摘する日本の文化財建造物における保存修理技 術が全体に定着する時期注 33) とほぼ重なることから、保存古材の取 り扱いの変遷に基づき、保存修理技術の定着過程の一端も明らかに なった。

ただし、膨大な量に上るとみられる保存古材の全体像やそれに対 応する方針の実態は依然として不明で、その解明にはなおも課題を 残寸注 34$)$ 。なお、令和元年に耐震対策工事が竣工した No.2-30 旧奈
良監獄北倉庫における 5,000 点を超える保存古材注 35$)$ のうに、一 棟の古材群の量が突出している事例や、令和 2 年に保存修理工事等 が竣工した No.2-32 旧富岡製系場西置䒽所では、設備機器を含む 276 点の保存古材を記録し注 36 )、近代の建造物の保存修理に特有な 古材群を保管する事例などもあり、近年の保存古材の取り扱いには、 新たな傾向を見出せることも記しておきたい。

注

注 1) 関野克『文化財と建築史』(鹿島出版会 (SD 選書 151) 1969.11)、伊藤延 男ほか『新建築学体系 50 歴史的建造物の保存』(彰国社, 1999.4)などで、 保存古材の重要性に触れている。また、1999 年イコモス木の委員会で採択 された「歴史的木造建造物保存のための原則」(前掲『新建築学体系 50 歴 史的建造物の保存』掲載の最終草案) 第 8 条では、「取り外した部材その他 の歷史的建造物の構成要素は、目録作成し、特徴的な標本は資料の一部々 して恒久的な収蔵室に保持するべきである」とされる。2017 年改訂「木造 建築遺産保存のための原則」(http://iiwc. icomos. org/assets/iiwc-2017principles-en2. pdf 参照)の第 27 条にも、保存古材に関する考え方は全く 改訂なく引き継がれ、国際的にもその重要性が認識されている。

注 2) 近年の保存古材に対寸る科学的調查研究の進展は、国立歴史博物館坂本 稔・中尾七重編『歴博フォーラム 築何年? 炭素で調べる古建築の年代研 究』(吉川弘文館, 2015.3)、坂本稔・横山操『樹木 ・ 木材と年代研究』(朝倉 書店, 2021.3) 詳しく、保存古材を使用した年輪年代法や炭素 14 年代法に よる年代研究が進められている。また保存古材を使用した樹種や植生の調 查研究として田鶴寿弥子「研究ノート建造物保存修理工事における部材の 樹種調査の現状」（『建築史学第七十二号』,建築史学会, 2019.3)がある。

注 3) 昭和 26〜28 年 $(1951 \sim 1953)$ に解体修理を実施した吉村家住宅で、工事 報告書に記載のない保存古材を発見し、重要文化財民家では最古の保存古 材である可能性を指摘した大野敏ほか「民家保存形態の類型および修復に おける成果と課題」『木造建造物の保存修復のあり方と手法』(独立行政法 人奈良文化財研究所, pp. 151-232, 2003.3) があるが、保存古材の変遷を考察 したものではない。また、鳴海祥博「現在行われている指定文化財の修復 の方針」（前掲『木造建造物の保存修復のあり方と手法』,pp. 69-76)は、行 政資料から国の保存修理に対する指導方針の変遷を検討としたものとして 注目されるが、保存古材の取り扱いだけに着目したものではない。

注 4) 重要文化財民家に所蔵する保存古材を報告した『重要文化財民家保存修 復資料木造建造物の保存修復のあり方と手法に関する調查研究参考資料』 (独立行政法人奈良文化財研究所, 2003. 3) がある。また法隆寺所蔵の保存古 材の調査内容を概報した海野聡「法隆寺所蔵古材調査 $1 」 『$ 奈良文化財研究 所研究紀要 2010』(独立行政法人奈良文化財研究所, pp. 34-35, 2010.6)、大 林潤「法隆寺所蔵古材調查 4一昭和大修理と古材の整理一」『奈良文化財研 究所研究紀要 2014』(独立行政法人奈良文化財研究所, pp. 12-13, 2014. 7) や 国立歷史民俗博物館所蔵の法隆寺の建造物の保存古材を報告した坂本稳他 「建造物古材による木材科学的資料研究」(前揭注 2)『樹木・木材と年代研 究, pp. 105-142) 及び唐招提寺の建造物の保存古材を報告した『唐招提寺部 材調查報告書』(唐招提寺, 2018.3) がある。だが、いずれも個別建造物の調 查で、保存古材の全体像を論じたものではない。

注 5)『文化財建造物保存修理補助事業 実務の手引き』(文化庁, 平成 15 年 (2003) 年 8 月初版, 平成 17 年 (2005) 3 月改訂, 平成 27 年 (2015) 6 月改訂, 平 成 30 年 (2018) 6 月最終改訂)。

注 6) 前掲注 5)『文化財建造物保存修理補助事業 実務の手引き』(最終改訂 版）の第一部第 3 章第 2 節の「8-1 竣工時の事務」「(6) 資料保存材・残材 等の処置」(p.29) 参照。なお、方針部分に対する改訂は初版から最終改訂 版まで見当たらない。

注 7) 文化財建造物における附指定とは、建造物と一体をなしてその価值を形 成している土地その他の物件で、附属的な建 造物及び建立、修理の年代を 示寸歷史資料等が指定されている。

注 8) 文部省「国宝建造物維持修理要項」(昭和 15 年 (1935) 3 月 7 日文部次官 決定) (『国宝保存総規・重要美術品等保存総規』国立公文書館所蔵, 3a-032$07 \cdot$ 昭和 59 文部 02534100$)$ 。

注 9) 関野克資料【資料番号 D-626】 東京文化財研究所所蔵、『文化財修理関係 資料』(文化財保護委員会, 1956.10) 所収

注 10)「第二 維持修理ノ方針」の(五)参照。

注 11) $「 3$ 建物の解体調查」「建物の仕様調書作製」(pp. 2-3)参照。

注 12)「II. 工事事務の心得」「6. 事業完了に伴う事務」「(10)残材・不用材等 
の処理」(p. 61) 参照。

注 13)『禅宗様建築 正福寺地蔵堂昭和修理記録』（普請研究第 29 号, 普請 研究会, 1989.9）所収の『國寶正福寺地蔵堂修理工事竣成報告書（實施仕様 書及び精算書习含ム』(文化庁所蔵, 1934.3) による。

注 14）『二荒山神社本殿・拝殿修理工事報告書』（二荒山神社, 1967. 1)

注 15) 平成 24 年 (2012)) 5 月 18 日付け文化庁報道発表資料(文化庁 HP) https://www. bunka. go. jp/seisaku/bunkazai/shokai/yukei_kenzobutsu/p df/yukei_kenzobutsu_240518. pdf 参照。

注 16）例えば、唐招提寺金堂の旧部材 22 枚 (表 1の No. 1-26 参照)に対し、

「(前略) 国宝の付（ママ）指定として、唐招提寺金堂の旧部材 (支輪板、天 井板) 同寺講堂の高座一対が追加指定され、従来建造物として比較的縁の薄 かった分野に保護の手が及んだ点は注目される。」『月刊文化財 92 号』(第 一法規出版株式会社, p. 21, 1971.5) とある。この他にも幾つかあるが、全て の附指定に対して示されていない。

注 17）『国宝東照宮本殿拝殿付属蒔絵屝修理工事報告書』（日光二社一寺文化 財保存委員会, 1965.3)

注 18）『国宝唐招提寺金堂修理工事報告書』（奈良県教育委員会, 2009. 12）

注 19)『重要文化財室生寺御影堂修理工事報告書』(奈良県教育委員会, 1976. 12)

注 20)『重要文化財苗村神社楼門他三棟修理工事報告書』（滋賀県教育委員 会, 1981.9)

注 21）『重要文化財衡梅院本堂修理工事報告書』(京都府教育委員会, 1978. 3) 注 22) 保存古材の目録や項目等で員数を確認できる工事報告書を対象とした。 注 23) 『国宝新薬師寺本堂 重要文化財地蔵堂 重要文化財南門 重要文化 財鐘楼工事報告書』(奈良県教育委員会, 1996.3)

注 24）『国宝法起寺三重塔修理工事報告書』（奈良県教育委員会, 1975. 1)

注 25) 前掲注 18)『国宝唐招提寺金堂修理工事報告書』

注 26）前掲注 13）『國寶正福寺地蔵堂修理工事竣成報告書（實施仕様書及び精 算書习含ム』

注 27）『法隆寺國寶保存工事報告書第二冊 國寶建造物食堂及び細殿修理工 事報告』（法隆寺國寶保存事業部, pp. 187-188, 1936.3)

注 28）『國寶興隆寺本堂修理工事報告』（國寶興隆寺本堂修理事務所, p. 4, 1938. 4)

注 29)『國寶石津寺本堂修理工事報告書』（滋賀縣國寶石津寺建造物修理出張 所, p. 7, 1938. 5)

注 30) 京都府立京都学・歴彩館所蔵

注 31)【昭-す-339（編次 19）】, 滋賀県立公文書館所蔵

注 32)【明-せ-75-3(編次 66) 】, 滋賀県立公文書館所蔵

注 33）「巻頭鼎談 文化財における修理の考え方と技術」『建築雑誌』（日本建 築学会, p. 25, 2001.5) において、鈴木嘉吉氏は「(前略) 文化財保護法(昭 25) の成立と同時に修理事業も一気に拡大された。人も現場も増え、それまで 確立した技術が全体に定着していくのが、昭和 40 年代ぐらいまでの時期 (後略)」と指摘する。

注 34) 近年では表 2 の No. 2-1 須波阿須疑神社本殿、No. 2-24 光明寺仁王門 及び No. 2-26 法隆寺中門のように、かつての修理工事の際の保存古材を工 事報告書に記載するものがあり、各所で保管された保存古材の実態が徐々 に明らかになりつつある。

注 35)『旧奈良監獄北倉庫耐震対策工事報告書』(旧奈良監獄株式会社, 2020.2) 注 36) 『旧富岡製糸場建造物保存修理工事報告書 (2) 国宝旧富岡製糸場西置 触所修理工事報告書【建造物編】』(富岡市, 2020.8) 


\author{
Yohei KIYONAGA*1 \\ ${ }^{* 1}$ Senior Specialist for Cultural Property, Agency for Cultural Affairs, M.Des.
}

The author wishes to explore the development of Japanese history for preservation of removed parts from architectural cultural properties while focusing on the selection criteria for its preservation.

Nowadays, based on one of the conservation principles, the original parts essentially would be reused in the conservation process, even the removed parts that are not available for reusing by the deteriorations, would be preserved as much as possible.

However, practically, it is too difficult to preserve whole things of removed parts including heavy deteriorated ones or amount of similarities like roof tiles by the problem of storing site. And actually, more valuable parts must be selected from the all removed parts by some selection criteria.

It seemed that this practical way has been gradually applied for the conservation process. However, so far there is no historical perspective for preservation of removed parts, especially focusing on the selection criteria in Japan, because of few conservation reports described about removed parts in the conservation project that would not be able to make it analyses. And then, the author take an analyses steps as bellow;

Initially by tracing the development of the selection criteria with the guidelines for the conservation project that have been gradually built up by the central government since the first half of the 20 th century.

Secondly by making the list of removed parts designated as national treasures and important cultural properties, and analyzing the separated parts into 6 types based on the characters and numbers, in order to unveil the reality of the selection criteria.

Thirdly by finding the first removed parts or the first report of ones, in order to make sure the situation before 1940 which there is no appearance of selection criteria.

Finally by concluding the development of Japanese history of preservation of removed parts from architectural cultural properties. 